\title{
Erythrocytes of uranium miners: the activity of the pentose phosphate pathway
}

\author{
Z. VÍCH, F. NOVOSAD, and V. BRYCHTOVÁ \\ Health Institute of Uranium Industry, Príbram, Czechoslovakia
}

\begin{abstract}
Vích, Z., Novosad, F., and Brychtová, V. (1970). Brit. J. industr. Med., 27, 287-290. Erythrocytes of uranium miners: the activity of the pentose phosphate pathway. The functioning of erythrocytes was studied by determination of the activity of the pentose phosphate pathway in 431 individuals - 221 uranium miners, 42 employees of a uranium ore trimming station ( 30 of whom were exposed), 36 former uranium miners, 32 coal miners, and 100 persons not working in mines and with no previous exposure. In the groups exposed to long-term occupational radiation, the activity of the pentose phosphate cycle was found to be enhanced. This finding was interpreted as evidence for a change in the functional state of the erythrocytes in exposed persons due to the effects of radiation on the genesis of red cells in the bone marrow.
\end{abstract}

In a previous paper, Vích and Krriklava (1970) analysed the results of examination of the red blood picture of uranium miners. No evidence of damage to erythrocyte production could be found.

In order to try to establish whether the erythrocytes also functioned normally, the activity of the pentose phosphate cycle (PPC) was studied. The PPC is one of the degradation pathways of glucose, and its inhibition after irradiation has been repeatedly demonstrated under experimental conditions (Šonka, Pospíšil, and Dienstbier, 1964; Šonka, Malina, Pospísil, and Dienstbier, 1965a; Šnka, Nosek, Vích, Pospísil, and Dienstbier, 1965b; Šonka, Hilgertová, Dienstbier, and Pospíšil, 1968). However, the PPC has never been investigated in individuals exposed to long-term radiation.

The reactions of the PPC had been established by 1953 (see, e.g., Šonka, 1956). In erythrocytes all the PPC enzymes and intermediates have been found (Prankerd, 1961; Palek, 1967), but the activity of the cycle is small and does not exceed $10 \%$ of total glucose utilization (Mirčevová, 1960; Hořejǔí, 1963; Carson and Frischer, 1966).

\section{Materials and methods}

\section{Groups studied}

The activity of the PPC in erythrocytes was examined in 431 persons. They were 100 healthy men applying for employment in the mines, but without previous exposure; 221 uranium miners from the Príbram region, working underground; 42 employees of the uranium ore trimming station, 12 of them auxiliary maintenance workers and 30 from the station itself (only the $\mathbf{3 0}$ from the station were exposed); 36 workers from a surface quarry of nonradioactive rock, all of whom were formerly uranium miners in Jáchymov but had left the mine three to six years previously; and 32 coal miners from the Ostrava region.

\section{Analytical methods}

The colorimetric methods described by Dubovský, Honsová, Kalousek, Palek, and Šonka $(1958$; 1959) were used (see also Hildmann and Zillman (1966)). These consist of the determination of the ribose formed and of the glucose utilized in a standardized sample of washed erythrocytes. The cells were incubated in a medium consisting of phosphate buffer and glucose, and, after deproteination, the supernatant was treated with a modi- 
fied Bial's reagent and the concentration of ribose and glucose was measured at $680 \mathrm{~nm}$ and $540 \mathrm{~nm}$ respectively. The cross-interference of both colour complexes was allowed for in calculating the results. Non-incubated parallel samples treated in the same way were used as controls. Of the total glucose utilized, the percentage utilized via the PPC, i.e., $100 \times$ ribose formed $\div$ glucose disappeared, is referred to as the percentage converted by the PPC.

The above method is in good agreement with others, including isotopic methods (Dubovský et al., 1958, 1959; Sonka, J., personal communication), but is considerably simpler.

\section{Results}

The uranium miners were divided into four groups according to the number of years of occupational exposure to radiation.

Table 1 presents the mean values for ribose production and for the percentage of glucose converted by the PPC. The results were compared by the $t$-test with the results for the group of non-miners, which had the characteristics of a normal healthy male population. The red cells for all groups of uranium miners produced more ribose, i.e., the PPC activity in them was higher. The percentage of glucose converted by the PPC was raised further because glycolysis was also a little depressed. From now onwards attention will be confined to the percentage of glucose which was converted by the PPC. The average values for former uranium miners and for those employees of the uranium ore trimming station who were exposed to radiation were also significantly increased; but auxiliary workers who were not exposed had normal levels, while in coal miners the percentage of glucose converted by the PPC was actually lower.

Although the mean values altered significantly with exposure, there was considerable spread and overlapping of the individual values. Table 2 shows how the values in each group were distributed over ranges of values fixed in relation to those in the

TABLE 1

Pentose Phosphate Cycle in Red Cells of Uranium Miners and Others

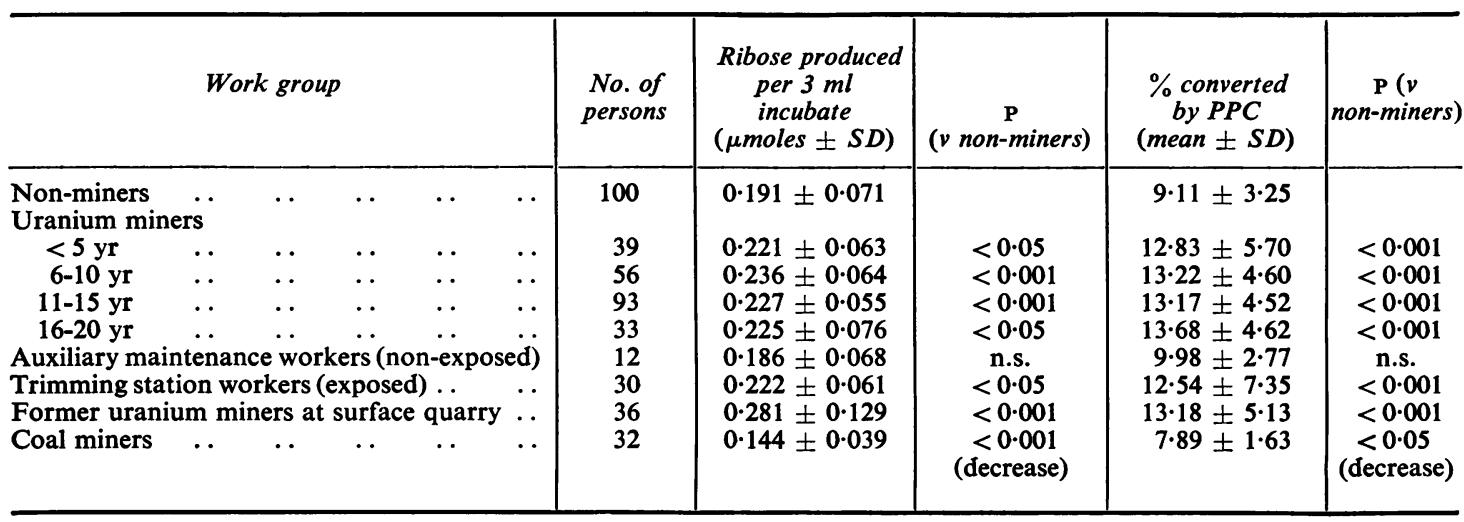

TABLE 2

Distribution of PPC VALUes

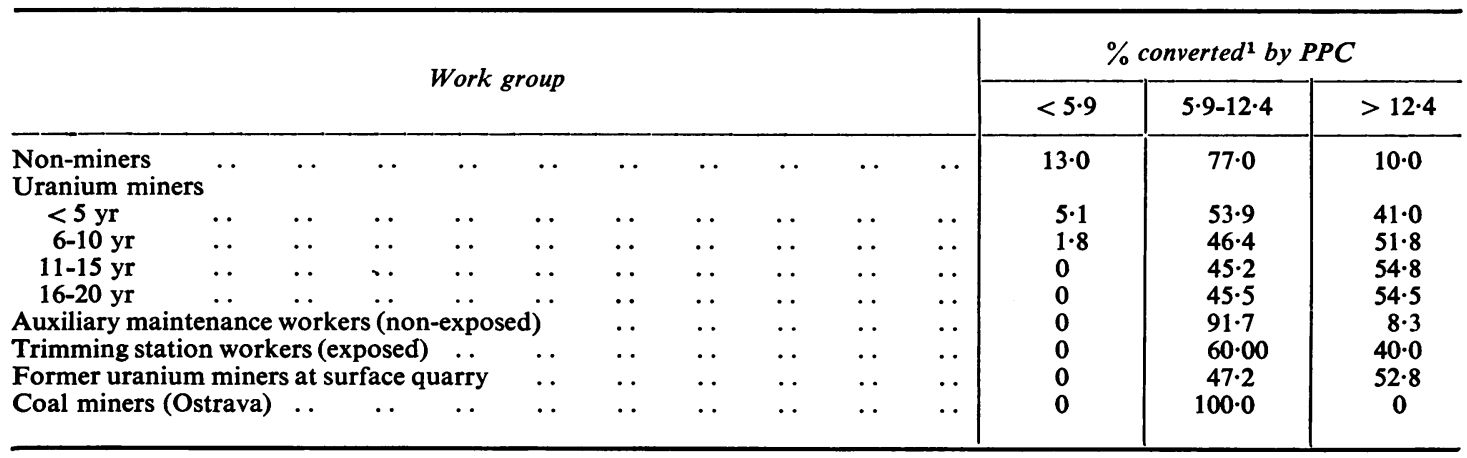

${ }^{1}$ These ranges are related to the mean values for the group of non-miners as described in the text. 
non-miners. These ranges were: below $5.9 \%$ (mean $-1 \mathrm{SD}$ for the non-miners); above $12.4 \%$ (mean + $1 \mathrm{SD})$ and between. The differences were evaluated statistically and were statistically significant to the same extent as before.

The effects of age were investigated. Table 3 shows the results for non-miners. There were no significant differences between the youngest and other age groups. Similarly, there were no significant differences with age between those exposed to radiation, i.e., the effect depended upon exposure, not age. When comparisons between work groups were confined to one age group the differences were very like those shown in Table 1 for the whole population. Table 4 shows the analysis for the 31 to 40 years age group.

TABLE 3

Percentage of Glucose Converted by PPC RELATED to AGE IN 100 NON-MINERS

\begin{tabular}{ccc|c|c|c}
\hline \multicolumn{2}{r|}{ Age (yr) } & & $\begin{array}{c}\text { No. of } \\
\text { persons }\end{array}$ & Mean $\pm S D$ & $\begin{array}{c}\mathbf{P} \\
(v \text { youngest } \\
\text { group })\end{array}$ \\
\hline$<20$ &. &.. & 14 & $8 \cdot 7 \pm 2 \cdot 3$ & \\
$21-30$ &. &. & 63 & $9 \cdot 2 \pm 3 \cdot 7$ & n.s. \\
$31-40$ &. &. & 12 & $8 \cdot 4 \pm 1 \cdot 7$ & n.s. \\
$>41 .$. &. &. & 11 & $9 \cdot 9 \pm 2 \cdot 3$ & n.s. \\
\hline
\end{tabular}

\section{Discussion}

The present investigation was begun because there was evidence of the influence of radiation on the PPC in erythrocytes (Šonka et al., 1964; Šnka et al., 1965a, 1968). After local irradiation for tumour-therapy there was an initial increase followed by a reduction of PPC activity (Šonka et al., 1965b). Also, the erythrocyte metabolism of uranium miners has not yet been studied thoroughly. Only alterations of the cholesterol content of erythrocytes and plasma had been observed (Adámek, 1967; Adámek, Roth and Štěpánková, 1969).

The contribution made to glucose utilization by the PPC might be influenced by many factors. The possibility of an increase in uranium miners caused by nutrition, by hormonal influences relating to stress or by muscular activity were eliminated by a comparison with coal miners, whose working conditions and lives do not differ to any appreciable extent. Hypoxia could not have contributed to the increased values in uranium miners, as the values obtained in former miners now working in the normal atmosphere of a nonradioactive surface quarry were also raised. No dependence on age or on any other features of the red cell picture (which were examined simultaneously) was found.

The common factor for all groups with an increased percentage conversion by the PPC in erythrocytes was long-term exposure to radiation in the working environment. In coal miners the percentages were lower than normal, presumably due to muscular work; so the increase in uranium miners, subjected to similar exacting physical strain, was probably even greater than a comparison with non-miners indicated (Tables 1 and 4).

The effect could not be due to the continuing external radiation level, otherwise the rise observed in the red cells of former uranium miners, whose exposure had ceased, could not be explained. It is concluded that the results are a long-term effect of exposure, due to the incorporation of radioactive isotopes with long half-lives into the bones (as described, e.g., by Jaworowski (1965) ) which could influence the production and formation of red cells in the bone marrow. The metabolic aberrations of erythrocytes in the blood stream are the effects of this. Morphological findings in the erythroblasts of the bone marrow and in peripheral erythrocytes of uranium miners support this view. There was an incidence of binuclear erythroblasts (Polák and Nováková, 1963), a slight shift of the mitotic phases of erythroid elements (Nováková, 1965), and the

TABLE 4

Percentage of Glucose Converted by PPC in 31-40 Years Age Group




presence of residues of nuclear matter in red cells in the blood (Krriklava, Vích, and Kosková, 1969).

It is likely that there are changes in the metabolism of the red cells of individuals exposed to long-term radiation, the effects of which are reduced by the increase of glucose oxidation via the pentose phosphate cycle. This might contribute to the maintenance of the functional efficiency of erythrocytes in respect of oxidation-reduction reactions and syntheses (Vích, 1968; Vích, Novosad, and Brychtová, 1968). If so, the alteration in the rate of the pentose phosphate pathway may be regarded as due to the operation of compensatory mechanisms.

\section{References}

Adámek, M. (1967). Changes of lipid metabolism in individuals with a long-term exposure to small doses of ionizing radiation. (In Czech.) Research report, Přibram.

__ Roth, K., and Stěpánková, M. (1969). Abweichungen im Lipidstoffwechsel als Grundlage eines Toleranztestes nach langfristiger Strahlungsexposition. Krebsarzt, 24, 306-311.

Carson, P. E., and Frischer, H. (1966). Glucose-6-phosphate dehydrogenase deficiency and related disorders of the pentose phosphate pathway. Amer. J. Med., 41, 744-761.

Dubovský, J., Honsová, M., Kalousek, F., Palek, J., and Sonka, J. (1958). Spectrophotometric measuring method of pentose phosphate pathway activity in erythrocytes. (In Czech.) Chem. Listy, $52,1796-1800$.

$\longrightarrow,-,-,-,-1959)$. Spektrophotometrische Methode zur Aktivitätsmessung des Pentosecyclus in Erythrozyten. Coll. Czechosl. chem. Comm., 24, 1234-1239.

Hildmann, W., and Zillmann, R. (1966). Bestimmung der Aktivät des Pentosezyklus im Erythrozyten bei Diabetikern und stoffwechselgesunden Personen. Z. ges. inn. Med., 21, 273-5.

Hořejši, J. (1963). Elements of Clinical Biochemistry in Internal Medicine. (In Czech) Státni Zdravotnické Nakladatelotsvi, Prague.
Jaworowski, Z. S. (1965). Radium $D$ in bones, hair and lymph nodes of uranium miners. Atompraxis, 11, 271-273.

Krriklava, J., Vích, Z., and Kosková, D. (1969). Nuclear residua in peripheric erythrocytes of persons exposed to chronic radiation. (In Czech.) Vnitřní. Lék., 15, 223-228.

Mirčevová, L. (1960). Sugar metabolism in human erythrocytes. (In Czech.) Dissertation, Prague.

Nováková, E. (1965). Distribution of mitotic phases of erythroblasts in people exposed to small doses of ionizing radiation. (In Czech.) Cas. Lék. čes., 104, 575-579.

Palek, J. (1967). Relationships between erythrocyte metabolism and hyperhemolysis. (In Czech.) Lék. Věda Zahr., 1, Suppl, pp. 172-184.

Polák, H., and Nováková, E. (1963). The incidence of binuclear normoblasts in workers exposed to small doses of ionizing radiation. (In Czech.) Review of research reports, No. II, Pŕibram, pp. 59-61.

Prankerd, T. A. J. (1961). The Red Cell. Blackwell, Oxford.

Sonka, J. (1956). Pentose Phosphates - Chemistry, Physiology, Clinic. (In Czech.) St. Zdrav. Nakl., Prague.

—_, Hilgertová, J., Dienstbier, Z., and Pospísil, J. (1968). The significance of the pentose phosphate pathway in radiobiology. (In Czech.) Cas. Lék. čes., 107, 18-20.

_, Malina, L., Pospísil. J., and Dienstbier, Z. (1965a). Effet des rayons $X$ in vivo sur le cycle pentosique des érythrocytes. Agressologie, 6, 205-212.

- Nosek, J., Vích, Z., Pospísil, J., and Dienstbier, Z. (1965b). The effects of local X-ray therapy of malignant tumours on the glycide metabolism of human erythrocytes. Atompraxis, 11, 157-158.

- PospíYil, J., and Dienstbier, Z. (1964). The pentose phosphate pathway and the radiation disease. (In Czech.) Cas. Lék. čes., 103, 1343-1344.

Vích, Z. (1968). Some indicators of the red blood components and of the functional status of erythrocytes of uranium miners. (In Czech.) Dissertation, Př́bram.

, and Kriklava, J. (1970). Erythrocytes of uranium miners: the red blood picture. Brit. J. industr. Med., 27, 83-85.

, Novosad, F., and Brychtová, V. (1968). The influence of chronic radiation on the pentose phosphate pathway of erythrocytes. (In Czech.) Research report, Přibram.

Received for publication November 3, 1969. 